\title{
Modelling Production Performance of Small Scale Production Plant
}

\author{
ManDjun Lee ${ }^{1}$, Prashobh Karunakaran ${ }^{1}$, RahmatAidil Djubair ${ }^{2}$, Heng Jong Ngu ${ }^{1}$
}

\author{
${ }^{1}$ Lecturer, School of Engineering and Technology, University College of Technology Sarawak, Malaysia \\ ${ }^{1}$ Senior Lecturer, School of Business and Management, University College of Technology Sarawak, Malaysia
}

\begin{abstract}
This paper is about development of a model to evaluate capacity utilization $(C U)$ of small scale production plants. The model employed short term production function with key independent variables of: plant operators, capital, $R \& D$, energy and machinery maintenance expenditure. $C U$ of small scale plant is the output and dependent variable for this study. The developed model is tested on a small scalewater production plant. The output results show that the average CU is $74 \%$ for six months of operations. The model test results revealed that all the inputs are positively correlated $(R>0.893)$ to $C U$, with major inputs are significantly contributing to $C U$. About $80 \%\left(R^{2}=0.797\right)$ of the inputs are consumed to achieve $C U$ of production process. The model estimated value was found to be close to actual recorded outputs ( $<2 \%$ difference). The model is found to be statistically significant at $95 \%$ confidence level with p-value less than 0.05. The developed model is useful for small scale plants in evaluating the production performance to achieve technical and economical sustainability. For further research in this topic, this study suggests building a model to optimize the contribution of inputs to $C U$ of small scale production plants.
\end{abstract}

Keywords - Capacity utilization, Operations research, Production performance, Small scale production.

\section{INTRODUCTION}

This study developed a model to evaluate capacity utilization of a small scale plant. This study is designed to apply the concept and knowledge of Operations Research in engineering into a small scale plant evaluating its capacity utilization. The developed model is tested in a small scale water production plant. The model will contribute to explore and identify bottlenecks, productivity gap and non-value added inputs. In the bigger picture, this model will contribute to achieve production sustainability in the aspect of economy and environment. Information to evaluate capacity utilization of a small scale plant is currently very limited in published material, whereas technically and economically feasible small scale plants are essential. Therefore, this work will contribute to the current knowledge stock of operations research. Essentially, the study will contribute to the foundation on capacity utilization of small scale plant domain. In this aspect, this study is new and novel.

\subsection{Problem Statement}

Nowadays, small scale production process is turning to the status of industry which implies that the involvement of man, machinery, materials, money and methods (5Ms) are key operating parameters to achieve low cost production. However, most small scale production plant lack of research and development capability to push them forward. To address all these issues, engineers and scientists need to pay attention to improve production performance as $\mathrm{CU}$ is one of the important keys in production performance measurement. Over the years, $\mathrm{CU}$ is also being improved for better measures and implemented in other industries such as automobile, electric generation, fishing, food processing and logistics [1]-[7]. To the best of our knowledge, there has not been any work on $\mathrm{CU}$ in the small scaleproduction. In this regard, the fundamental questions to get solution of the stated problems are:

1. What empirical model is required that includes all key operating inputs of small scale production plant to evaluate $\mathrm{CU}$ ?

2. How does the developed model contribute to evaluate $\mathrm{CU}$ in an operating condition of a small scale production plant?

\subsection{Research Objectives}

This study has two specific objectives:

(i) To develop a CU model for small scale production plant

(ii) To test the $\mathrm{CU}$ model in an operating small scale production plant

\subsection{Novelty of Study}

Majority of the publications focused on production output, performance of machines related to output, production cost, pollutions and energy consumption. Publications on source 
of operations management inefficiency of production plant is very limited. The output of small scale production plant depends on inputs such as labour, energy, maintenance, research and development (R\&D) as well as capital. How these inputs quantitatively relate to output is also limited in the literature. This work developed a model with all major inputs (capital, labour, maintenance, energy, R\&D), output (CU of small scale plant) and the contribution from each input to $\mathrm{CU}$ that can be measured quantitatively. The developed model will contribute to explore and identify bottlenecks, productivity gap and non-value-added inputs. In this aspect, necessary decisions could be taken to overcome the inefficiencies of the small scale production plant. Therefore, this work will definitely add new knowledge in the stock of present water production domain.

\subsection{Concepts of Capacity Utilization \\ II. LITERATURE REVIEW}

The most used definition of Capacity Utilization (CU) is the ratio of actual output to the potential output. Potential output has various definitions from the perspective of engineering and economy [8]-[13]. In the perspective of engineering economy, CU measures the amount of inputs that are utilized to produce outputs from a plant production cycle. $\mathrm{CU}$ is an indicator in whether a plant can accommodate future growth without extra investment. CU is also being used to explain some important factors in production economics such as productivity, profit, assessing growth, employment generation and production cost [14]-[16]. In engineering operations point of view, $\mathrm{CU}$ measures how much of the existing output of the production facility that is being utilized, and plans could be devised to improve the production efficiency to meet customer demand [17]. In macroeconomic perspective, $\mathrm{CU}$ of manufacturing industries decrease sharply during economic recession because of the decrease in aggregate demand for products. Industrial practice proves that when $\mathrm{CU}$ is decreasing, the industry is most likely operating with a negative output gap that contributes to increase the unit cost of production. It is because the negative output gap acts as non-value-added inputs. Likewise, if $\mathrm{CU}$ increases, then the industry is operating with a positive output gap which contributes to reduce the unit cost of a product [18]. This statement is supported by past literatures that increasing capacity utilization contributes to reduce overall cost such as setup, maintenance, inventory holding, shortage cost and cost incurred by low quality products [19]. Factors affecting CU in production process are such as machineries transforming capability, skill of machine operators, working environment, degree of maintenance in machineries and raw material quality [20].

$\mathrm{CU}$ is an important tool for production and operations management to evaluate production performance and formulate strategy to reduce non-value input that appears as productivity gap [5], [17], [21]. Past literatures demonstrated increase in CU contributes to reduce overall cost such as setup, maintenance, inventory holding, shortage cost and quality cost [19], [22]. Better CU, efficient capacity planning and management are the key to improve production performance [23]-[26]. Over the years, $\mathrm{CU}$ is also being improved for better measures and implemented in other industry such as automobile, electric generation, fishing, food processing, logistics, [1]-[3]. The preliminary literature survey report states that was done at the earlier stage of this study, there has not been much work of $\mathrm{CU}$ in water processing industry. In this regard, the outcome of this study would fill up this gap and contribute to assist manager of small scale water processing industry to evaluate $\mathrm{CU}$ for achieving sustainability.

\subsection{Key Operating Parameters of Small Scale Production Plant}

Personnel or labour workforce is one of the main input in production operations. Skill sets that owned by labourwillhave huge impact on the output quality. Skill sets are influenced by the level of education and experience and it is crucial factor for any production facility in to grow[27]. In addition, personnel cost is an important cost component in a production facility. Personnel cost of production consists of direct and indirect workforce cost, which means wage for machine operators and maintenance personnel at production plant is direct personnel cost while cost for management or supporting department is considered as indirect personnel cost [28]. Labourcost made up a significant portion of most production cost structure. There are methods to reduce labour costs. These include the adoption of new technology, efficient workforce management, promote labour training, and outsourcing [29]. Shahidul and Shazali (2011) found that favourable working environment, provide trainings to workforce will contribute to increase labour productivity. This concept is applicable to production plant as personnel cost constitutes about 1 to $6 \%$ of production cost [30].

Research and development (R\&D) activities are essential effort contributes to success of production technology by making it more significant over the years [31]. Although present production technology is well developed, however, there are still rooms for improvements in efficiency, reliability, simplicity and cost reduction. In this regard, huge 
amount of $\mathrm{R} \& \mathrm{D}$ efforts in production should be directed towards improving and optimizing the existing production technology. The topics of $\mathrm{R} \& \mathrm{D}$ that gaining attentions are such as [32]:

- Development of alternative energy sources

- Mitigation and control of scaling and fouling

- Alternate materials of construction

- Optimization of process design

- Improvements in components design

- Control systems to optimize consumables consumption.

In this aspect, the expenditure of $R \& D$ provides indication of engineering research capability. R\&D efforts and production performance are connected mutually to improve competitiveness in the global market [23]. R\&D expenditures are incurred in the midst of the existing production components and introduces new equipment aims to optimize the existing production performance. $R \& D$ is needed not only in large scale production plant process and also in small scale to support various applications of production processes. The strength of production machinery operations is positively associated with performance of maintenance activities [17]. Literature suggests that maintenance activities are responsible to restore plant machineries back to or close to original health condition [33]. Machinery capacity utilization is a powerful productivity indicator which measures how much installed productive capacity is being utilized with respect to actual production output. Generally, machinery productivity is positively associated with capacity utilization and capacity utilization depends on machineries condition; this creates linkage between maintenance and capacity utilization. Maintenance activities cannot be separated from production machineries as it is needed a manufacturing plant for utilizing its capacity to optimize production performance. Good implementation of maintenance strategy not only improves machinery efficiency and effectiveness but also brings significant improvements in plant capacity utilization. Consequently, the production system being benefited by becoming more productive. Indeed, quality maintenance work will contribute to increase CU and product quality [13]. Successful long term production depends on proper maintenance of production system. It is estimated that production maintenance is representing about $10 \%$ to $40 \%$ of total production operation cost [17]. In this category, the included costs of spare parts, and consumable for maintenance activities. Spare parts cost includes all the replacement parts for the machinery in the aspect of mechanical, electrical, and fluid systems [34]. Expenses relating to machinery hardware such gasket, bearing, lubricants, cooling agent, screw, bolts and nuts, O-rings and others are categorized as consumable cost [35]. Both facility and maintenance costs are important for a water production plant to achieve its economical sustainability [33]. The cost components should get higher priority from plant management in order to sustain. In other words, production system maintenance has to be optimized so that the water production plant is sustainable.

\section{METHODOLOGY}

This is an applied research in engineering domain consist of operations research, small scale production system hardware, production theories, capacity utilization theories, and production economics. Production and CU related theories have been applied to the water production process to develop the CU model. The methods and study process have concentrated on small scale water production process machinery to evaluate production performance.

\subsection{Characteristics of Variables Used}

Table.1: Explanatory Variables

\begin{tabular}{|c|c|}
\hline \multicolumn{2}{|c|}{ Research Variables } \\
\hline $\begin{array}{l}\text { Dependent } \\
\text { Variables }\end{array}$ & Definition of Variables \\
\hline $\begin{array}{l}\text { Capacity } \\
\text { Utilization } \\
(\mathrm{CU})=\sum_{\mathrm{i}}^{\mathrm{n}} \frac{\mathrm{Q}_{\mathrm{a}}}{\mathrm{Q}_{\mathrm{p}}} \\
\mathrm{CU} \quad=\quad \mathrm{f} \\
(\mathrm{K}, \mathrm{L}, \mathrm{M}, \mathrm{D}, \mathrm{E})\end{array}$ & $\begin{array}{l}\text { CU of production system depends on } \\
\text { actual product output, } \mathrm{Q}_{\mathrm{a}} \text { and potential } \\
\text { output } \mathrm{Q}_{\mathrm{p}} \text {. The output of the process is } \\
\text { output desalinated water measured by } \\
\text { product water volume Litre in one } \\
\text { operating day (L/day). Product water } \\
\text { output must conform with quality as per } \\
\text { World Health Organization drinking } \\
\text { water quality which is pH of water is } \\
\text { recommended at range } 7.0-8.5 \text {, total } \\
\text { hardness is less than 100mg/L, turbidity } \\
\text { (total suspended solids) is less than } \\
\text { 5.0NTUs, and total dissolved solids to be } \\
\text { less than 1000mg/L [36]. CU depends on } \\
\text { inputs such as plant operators, } \\
\text { maintenance activities, capital, energy, } \\
\text { research and development investment to } \\
\text { achieve higher production performance } \\
\text { [13], [17], [37]. Inefficient part of water } \\
\text { production process act as non-value } \\
\text { inputs ultimately contributes to reduce } \\
\text { capacity utilization of water production } \\
\text { performance [38]. }\end{array}$ \\
\hline
\end{tabular}




\begin{tabular}{|c|c|c|c|}
\hline \multicolumn{2}{|c|}{ Research Variables } & \multicolumn{2}{|c|}{ Research Variables } \\
\hline $\begin{array}{l}\text { Independent } \\
\text { Variables } \\
\text { (Descriptive } \\
\text { Variables) }\end{array}$ & Definition of Variables & & $\begin{array}{l}\text { replacement cost, machineries } \\
\text { breakdown and preventive maintenance } \\
\text { cost. Typical expenditure for } \\
\text { maintenance is about } 5 \% \text { to } 8 \% \text { of total }\end{array}$ \\
\hline \multicolumn{2}{|l|}{ Inputs } & & \\
\hline Capital (K) & $\begin{array}{l}\text { The capital input of the process includes } \\
\text { all expenditures associated with system } \\
\text { implementation from the beginning of } \\
\text { time of production project through } \\
\text { engineering design, financing, } \\
\text { construction, installation, commissioning } \\
\text { and acceptance testing to start operating } \\
\text { [39]. In this study, the major focus is on } \\
\text { production system. In this aspect, the } \\
\text { capital cost focus on production system } \\
\text { cost and other operating cost associated } \\
\text { with machinery such as insurance and } \\
\text { amortization. }\end{array}$ & \multirow[t]{2}{*}{ Energy (E) } & $\begin{array}{l}\text { The energy is essential input resource for } \\
\text { the plant machinery operations. Major } \\
\text { concern with energy usage is } \\
\text { environmental responsibility and low } \\
\text { cost. Energy consumption contributes to } \\
\text { major portion of water production cost } \\
\text { and can reach up to } 45 \% \text { of total water } \\
\text { production cost [42]. This is due to high } \\
\text { pressure equipment in the process such } \\
\text { as pump. Energy input is measured by } \\
\text { cost of energy consumed by small scale } \\
\text { water production plant. Average energy } \\
\text { consumption range from } 3.2 \mathrm{kWh} / \mathrm{m}^{3} \text { to }\end{array}$ \\
\hline \multirow[t]{2}{*}{$\begin{array}{l}\text { Plant Operators } \\
\text { and } \\
\text { Maintenance } \\
\text { Staff (L) }\end{array}$} & \multirow{2}{*}{$\begin{array}{l}\text { Plant operators in charge of operating } \\
\text { daily operations. Maintenance staff } \\
\text { involve in all activities related to } \\
\text { maintenance such as membrane cleaning, } \\
\text { preventive maintenance schedule and } \\
\text { breakdown maintenance. Both plant } \\
\text { operators and maintenance staff have } \\
\text { direct and significant impact on output } \\
\text { productivity [40]. Operators with higher } \\
\text { skills will increase production capacity. } \\
\text { This signifies high degree of skill could } \\
\text { be considered as high value adding to } \\
\text { water production process and } \\
\text { significantly correlated with productivity } \\
\text { [20]. }\end{array}$} & & $\begin{array}{l}12 \mathrm{kWh} / \mathrm{m}^{3}[43] \text {. Energy consumed in the } \\
\text { production process are measured by } \mathrm{kWh} \\
\mathrm{x} \text { cost per unit to get the total cost of } \\
\text { electrical energy used in production } \\
\text { process. The tariff is based on energy } \\
\text { provider with the rate of } 31.5 \mathrm{Sen} \text { (MYR) } \\
\text { for each } \mathrm{kWh} \text {. }\end{array}$ \\
\hline & & \multirow[t]{2}{*}{$\begin{array}{l}\text { Research and } \\
\text { Development } \\
\text { (D) }\end{array}$} & \multirow[t]{2}{*}{$\begin{array}{l}\text { R\&D activities support the efforts to } \\
\text { innovate or continuous improvement on } \\
\text { the existing water production process for } \\
\text { achieving higher productivity, more } \\
\text { environmental friendly and reduce water } \\
\text { production cost [20]. It is valued by the } \\
\text { budget of R\&D per year. Typical cost for } \\
R \& D \text { is about } 5 \% \text { of total production } \\
\text { cost. }\end{array}$} \\
\hline Maintenan & Maintenance activities are essential to & & \\
\hline
\end{tabular}

Activities $(\mathrm{M}) \quad$ reduce machinery breakdown and reduce membrane fouling. Membrane fouling factors are the determinants of water production performance. Fouling factors contribute to increase operating pressure across membranes and this reduces $\mathrm{CU}$, product water production and lifespan of membranes [41]. Therefore, maintenance activities are crucial to remove membrane fouling. Good performance practices lead to higher product water quality, $\mathrm{CU}$ and reduce downtime [17]. The input of maintenance in the process is calculated by the membrane

\subsection{Description of Case Study}

A small scale desalination plant was selected to conduct model testing. The small scale water production plant contributes to solve local water shortage problem. The characteristics of feed water is water with high turbidity (3100NTU), salt content of 35,000 mg/litre (ppm). These characteristics of feed water is classified as brackish and city polluted water (BWCP) [21]. The plant produce water at the rate of about 5000L/day. he basic components of the plant consist of water intake, bio-reactor, dual media filter, ultrafiltration membrane and production membrane pack. There are two (2) main stages of water treatment process: pretreatment and filtration process. 


\subsection{Model Building and Testing Procedure}

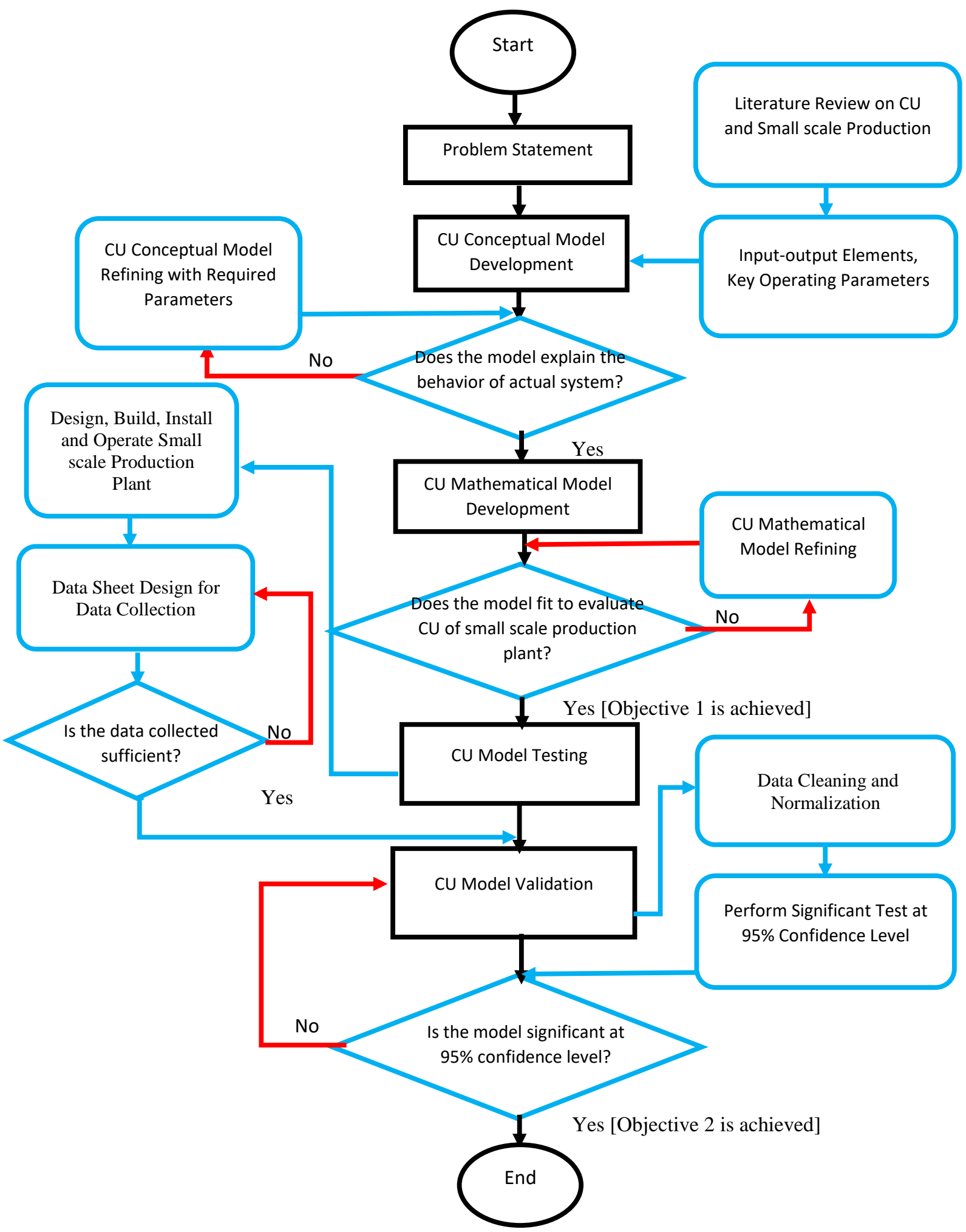

Fig.1: Methodology of Study 


\section{RESULTS AND DISCUSSIONS}

\subsection{Model Building}

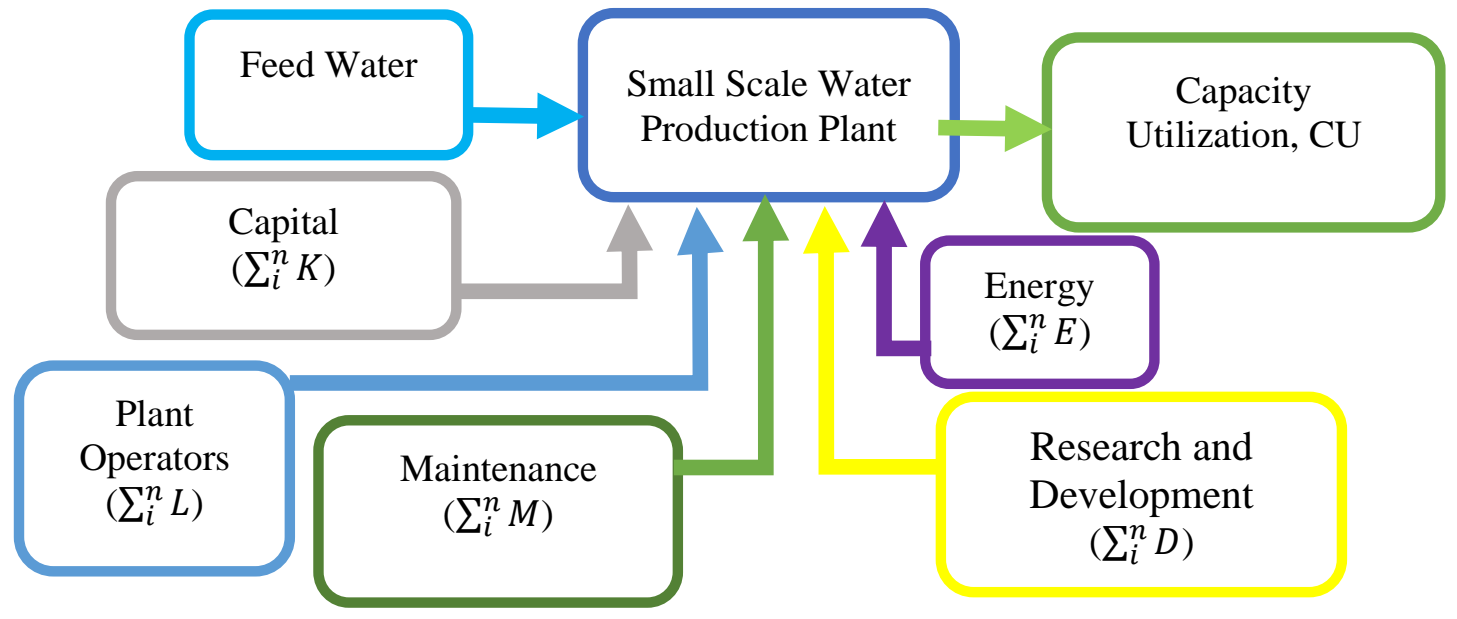

Fig.2: Combined Inputs with Mathematical Expressions

The CU model is built by combining all explanatory variables and is shown in Figure 2.

As [13], [37], [44], [45] suggested that input and output are not linearly correlated in any production process. Based on these references and mathematical expressions from the theory of production [44], theory of elasticity [45], the short-term production function of small scale production plant is shown in Equation 1 with $\mathrm{CU}$ as production output. $\mathrm{CU}(\mathrm{t})=\mathrm{A} \cdot \mathrm{K}^{\alpha 1} \mathrm{~L}^{\alpha 2} \mathrm{E}^{\alpha 3} \mathrm{D}^{\alpha 4} \mathrm{M}^{\alpha 5}$

From engineering perspective, since Equation 1 is nonlinear, the parameters are difficult to estimate. To simplify the parameters and make it linear, the Equation 1 is converted to logarithm linear form. The logarithm form of this production function is presented in Equation 2.

$\log (\mathrm{CU})=\log (\mathrm{A})+\alpha 1 \log (\mathrm{K})+\alpha 2 \log (\mathrm{L})+\alpha 3 \log (\mathrm{E})+$ $\alpha 4 \log (\mathrm{D})+\alpha 5 \log (\mathrm{M})$

Here, $\mathrm{CU}(\mathrm{t})=$ Capacity utilization of small scale production plant output over time t. $\mathrm{K}=$ capital of small scale production plant. $\mathrm{L}=$ wages of plant operators, $\mathrm{E}=$ energy consumed in small scale production process, $\mathrm{D}=\mathrm{R} \& \mathrm{D}$ expenditures used to improve small scale production plant $\mathrm{CU}, \mathrm{M}=$ Maintenance expenses and $\mathrm{A}=$ transformation factor from inputs to CU.

Equation 1 and 2 are stochastic functions with output of $\mathrm{CU}$ and input variables affected by time, t. Input variables such as labour skill will grow with respect to time due to trainings received and contributes to improve $\mathrm{CU}$ of plant machinery. In this aspect, $\mathrm{CU}$ indeed depends on input variables and changes with respect to time.

Equation 2 could be used to estimate the $\mathrm{CU}$ of small scale production plant. The equation shows that the value of
CU (t) depends on the elasticity of capital $(\alpha 1)$, plant operators $(\alpha 2)$, energy ( $\alpha 3), R \& D(\alpha 4)$ and maintenance $(\alpha 5)$.

\subsection{Model Testing and Validation}

This study uses six months operating data from the small scale production plant. Equations 1 and 2 are used to evaluate the contribution of inputs to CU. The findings are reported in Table 2.

Table.2: Model Estimate of Small Scale Production Plant

\begin{tabular}{|c|c|}
\hline & $C U$ \\
\hline Parameters & Model Estimate \\
\hline A & 0.1660 \\
\hline$\alpha 1$ & 0.0350 \\
\hline$\alpha 2$ & 0.1750 \\
\hline$\alpha 3$ & 0.0320 \\
\hline$\alpha 4$ & 0.0700 \\
\hline$\alpha 5$ & 0.0030 \\
\hline $\mathrm{R}$ & 0.8930 \\
\hline$\overline{\mathrm{R}^{2}}$ & 0.7970 \\
\hline $\mathrm{DW}$ & 2.0970 \\
\hline
\end{tabular}

The estimated Durbin-Watson (DW) value is 2.097 which is within acceptable limit $(\mathrm{DW} \approx 2)$. This indicates that the inputs are independent of each other without any significant autocorrelation among inputs. From Table 4.1, the value of $\mathrm{R}=0.893$ expressed that there is a high degree of positive relationship between the $\mathrm{CU}$ and independent variables, 
capital, plant operators, energy, R\&D, and maintenance. It indicates that if the above mentioned independent variables increase then $\mathrm{CU}$ also increase accordingly. The value of effect size $\mathrm{R}^{2}=0.797$ indicates that $79.7 \%$ of variance in $\mathrm{CU}$ model can be predicted from capital, plant operators, energy, R\&D and maintenance. It means $79.7 \%$ of inputs are used achieve higher production $\mathrm{CU}$ in small scale production system operations. The information from Table 2 is being fitted into Equation 1 and 2 to generate the model to evaluate $\mathrm{CU}$ of small scale production plant and logarithm form of the equation is shown in Equation 3.

$\operatorname{LogCU}=-0.780+0.035 \log \mathrm{K}+0.175 \log \mathrm{L}+$

0.032LogE + 0.07LogD + 0.003LogM

The final form of $\mathrm{CU}$ model is shown in Equation 4

$\mathrm{CU}(\mathrm{t})=0.166 \mathrm{~K}^{0.035} \mathrm{~L}^{0.175} \mathrm{E}^{0.032} \mathrm{D}^{0.070} \mathrm{M}^{0.003}$

The model testing results are shown in Table 3 .

Table.3: Differences Between Estimated Value and Actual Value of Small Scale Production Plant $C U$

\begin{tabular}{|c|c|c|c|}
\hline $\begin{array}{c}\text { Mon } \\
\text { th }\end{array}$ & $\begin{array}{c}\text { Estimated CU } \\
\text { Value }\left(\mathbf{V}_{\mathbf{E}}\right)\end{array}$ & $\begin{array}{c}\text { Actual CU } \\
\text { Value }\left(\mathbf{V}_{\mathbf{A}}\right)\end{array}$ & $\begin{array}{c}\text { Difference } \\
\mathbf{( D \%})\end{array}$ \\
\hline 1 & 0.7921 & 0.8068 & 1.822013 \\
\hline 2 & 0.7728 & 0.7814 & 1.100589 \\
\hline 3 & 0.7449 & 0.7553 & 1.376936 \\
\hline 4 & 0.7112 & 0.7206 & 1.304469 \\
\hline 5 & 0.6746 & 0.6851 & 1.532623 \\
\hline 6 & 0.6483 & 0.6605 & 1.847086 \\
\hline
\end{tabular}

Results from Table 3indicates that model estimate value is near to the actual value. The difference found is between $1.10 \%$ to $1.85 \%$. This result demonstrates that the developed model is quite suitable for measuring $\mathrm{CU}$ of small scale production plant with production inputs of capital, plant operators, energy, R\&D and maintenance.

\subsection{Scenario Analysis of Findings}

The findings indicate that the average $\mathrm{CU}$ of plant machinery for six months is about $73.5 \%$. The model estimate indicates all the inputs are positively correlated $(\mathrm{R}>0.893)$ to $\mathrm{CU}$. Overall, about $79.7 \%\left(\mathrm{R}^{2}=0.797\right)$ of the inputs being consumed to achieve $\mathrm{CU}$ of production process. Table4 summarized the conversion efficiency $\left(\mathrm{R}^{2}\right)$ of the major inputs to $\mathrm{CU}$ of the small scale water production plant.
Table.4: Conversion Efficiency of Variables

\begin{tabular}{|c|c|c|c|}
\hline Variables & Performance & p-value & Comment \\
\hline $\begin{array}{l}\text { Capacity } \\
\text { Utilization } \\
\text { (CU) }\end{array}$ & $\begin{array}{l}73.5 \% \\
(>60 \%)\end{array}$ & - & $\begin{array}{l}\text { Achievement is } \\
\text { significant }\end{array}$ \\
\hline $\begin{array}{l}\text { Plant and } \\
\text { Maintenance } \\
\text { Operators (L) }\end{array}$ & $\begin{array}{l}74.4 \% \\
(>50 \%)\end{array}$ & $0.001 * *$ & $\begin{array}{lr}\text { Input } & \text { is } \\
\text { significant and } \\
\text { efficiently } \\
\text { contributed to } \\
\text { output } \\
\text { production }\end{array}$ \\
\hline Capital (K) & $12.7 \%$ & $0.001 * *$ & $\begin{array}{l}\text { Input is } \\
\text { significant but } \\
\text { not efficiently } \\
\text { utilized }\end{array}$ \\
\hline $\begin{array}{l}\text { Plant } \\
\text { Maintenance } \\
\text { (M) }\end{array}$ & $0.05 \%$ & 0.45 & $\begin{array}{l}\text { Achievement is } \\
\text { not significant } \\
\text { and highly } \\
\text { inefficient }\end{array}$ \\
\hline Energy (E) & $45.9 \%$ & $0.001 * *$ & $\begin{array}{l}\text { Input is } \\
\text { significant but } \\
\text { not efficiently } \\
\text { utilized }\end{array}$ \\
\hline $\begin{array}{l}\text { Research and } \\
\text { Development } \\
\text { (R\&D) }\end{array}$ & $38.6 \%$ & $0.001 * *$ & $\begin{array}{l}\text { Input is } \\
\text { significant but } \\
\text { not efficiently } \\
\text { utilized }\end{array}$ \\
\hline
\end{tabular}

**Variable significant ( $\mathrm{p}$-value $<0.05$ ) with one-tailed test at $95 \%$ confidence level

Major inputs are significant (p-value $<0.05$ ) except for plant maintenance ( $p$-value $>0.05$ ). In the aspect of contribution, only plant and maintenance operators (L) are significant $\left(\mathrm{R}^{2}=74.4 \%\right)$. Education and experience of plant and maintenance operators are the important factors for small scale production plant to sustain. Cobb-Douglas (1928) even demonstrated that without contribution of labour there would be no outputs. However, to optimize the performance of plant operators, it is suggested to improve working environment. Favourable working environment such as quality management, having friendly superior, liking the physical surrounding in the work place, job security, sustainable remuneration package, availability of food and drink in the workplace are the contributory factor for motivating plant workforce towards achieving higher productivity[46], [47]. Shahidul and Shahzali (2011) found a strong linkage between favourable working environment and productivity. In this aspect, improving the existing working environment would contribute to improve plant operators' performance. 
The elasticity of energy for $\mathrm{CU}$ model of small scale production plant is 0.032 . This implies a change of $10 \%$ units of energy at inputs will result in CU change of $0.32 \%$. The findings indicated the energy is being overspent on auxiliary plant operations such as lighting system and surveillance camera security system. Moreover, the long feed water delivery line (200ft) from source water to pretreatment process operations consumed more energy than to overcome osmotic pressure in the production membrane for salt separation process[48]. To improve the contribution of energy to $\mathrm{CU}$ of the small scale production plant, the use of energy recovery devices are suggested[49], [50]. The use of energy recovery devices such as Pelton turbine proven to reduce the consumption of energy in production plant and this lead to potential savings and higher CU[51].

The elasticity of maintenance for CU model of small scale production plant is 0.003 . This implies a change of $10 \%$ units of energy at inputs will result in CU change of only $0.003 \%$. This finding suggest maintenance in the testing plant contributes only to increase availability through breakdown maintenance; preventive maintenance appears as nonvalue added input in six months of operations. The reason for such scenario might be due to the fact that the small scale production plant for this study has just operated for just about six month. In this aspect, the plant system is still considered new and no major maintenance activities are needed to remove scaling in the production membrane; pump servicing is not required; no leakage in the piping system that would reduce the availability of the plant For short-term production, the effect of maintenance effort is usually not noticeable and thus maintenance would be appeared as productivity gap that contributes to reduce the efficiency of any production plant[17], [52], [53].

Model validation is being done by using SPSS software statistical significance one-tailed test at $95 \%$ confidence level. The result indicates p-value obtained is about 0.01 $(\mathrm{p}<0.05)$ and this indicates the model is statistically significant. The actual and estimated values of $\mathrm{CU}$ have maximum difference about $1.85 \%$. The findings demonstrate the developed CU model is indeed quite fit to evaluate $\mathrm{CU}$ of small scale production plant. In this aspect, the goal of this study has been achieved.

\section{CONCLUSIONS AND RECOMMENDATIONS}

The study of CU of small scale production plant is very limited. Very few solutions or experiences that could be found from scientific publications. On the other hand, technical approaches used by large production plants are available, but might not fully applicable to small scale production plant machinery. Practice from large scale plant shows that the contribution of capital, maintenance, plant operators, $\mathrm{R} \& \mathrm{D}$ and energy is positively associated with $\mathrm{CU}$ because CU plays vital role in production performance especially in production machinery. However, a model to evaluate $\mathrm{CU}$ of small scale production system is could not be found in the literature. In this aspect, this gap has raised logical questions of what model able to explain the $\mathrm{CU}$ conceptual behavior of small scale production system, what mathematical model could be used by small scale production plant managers to evaluate the process machinery, how the developed CU model contribute to evaluate production performance and contributions of inputs and is the developed model significant to evaluate CU. This study concludes by answering these questions. This study recommends a study program to optimize inputs for small scale production plant.

\section{ACKNOWLEDGEMENT}

The authors would like to thank University College of Technology Sarawak for funding the publication this research project.

\section{REFERENCES}

[1] D. A. Hashim, "Capacity Utilization in Indian Airlines," Delhi, India, 2003.

[2] C. J. Morrison, "Productivity Measurement with Nonstatic Expectations and Varying Capacity Utilization: An Integrated Approach,” J. Econom., vol. 33, no. 1, pp. 51-74, 1986.

[3] D. Zhang, "Studies in IT: Capacity Utilization and Option Market Information," University of Calgary, 2013.

[4] C. I. Hsu and H. C. Li, "An integrated plant capacity and production planning model for high-tech manufacturing firms with economies of scale," Int. J. Prod. Econ., vol. 118, no. 2, pp. 486-500, 2009.

[5] S. Ray, "A Post-Liberalization Period Analysis of Industry Specific Economic Factors Affecting Capacity Utilization in Indian Aluminium Industry," Dev. Ctry. Stud., vol. 2, no. 1, pp. 9-16, 2012.

[6] L. R. Klein and R. S. Preston, "Some new results in the measurement of capacity utilization," Am. Econ. Rev., pp. 34-58, 1967.

[7] A. Jakubovskis, "Flexible production resources and capacity utilization rates: A robust optimization perspective," Int. J. Prod. Econ., vol. 189, no. March, 
pp. 77-85, 2017.

[8] I. Johansen, "Production functions and the concept of capacity," Collect. Econ. Math., vol. 2, pp. 46-72, 1968.

[9] L. Klein and V. Long, "Capacity utilization: concept, measurement, and recent estimates," Brookings Pap. Econ. Act., vol. 73, pp. 743-756, 1973.

[10] E. Berndt and C. Morrison, "Capacity utilization measures: underlying theory and an alternative approach," Am. Econ. Rev., vol. 71, no. 2, pp. 48-52, 1981.

[11] T. Coelli, E. Grifell-Tatje, and S. Perelman, "Capacity utilisation and profitability: a decomposition of short run profit efficiency," Int. J. Prod. Econ., vol. 73, no. 3, pp. 261-278, 2002.

[12] Klein and R. Lawrence, "Some theoretical issues," Econometrica, vol. 2, pp. 272-286, 1960.

[13] M. I. Shahidul et al., "Measuring Production Capacity Utilization and Its Impact on Manufacturing Performance and Environment," in Energy and Environment, 2013.

[14] F. R. James, "Measuring capacity utilization in manufacturing," FRBNY Q. Rev. Winter 1976, pp. 1328, 1976.

[15] S. Hemanta, "Capacity utilization in small scale industries of India: some empirical evidence from under developed industrial structure," J. Soc. Econ. Stat., vol. 1, no. 1, pp. 39-53, 2012.

[16] Z. Lai, "Capacity utilization and productivity analysis in the Canadian food manufacturing industry," The University of Guelph, 2015.

[17] C. H. Ting, M. I. Shahidul, S. T. S. Shazali, and Y. Abdullah, "Measuring Contextual Impact of Maintenance on Machinery Capacity Utilization and Environment," in 6th Engineering Conference, 2013.

[18] B. Richard, J. A. Nicholas, and F. J. Robert, Operations management for competitive advantage, 9th Editio. The Mc Graw Hill Publication, 2002.

[19] K. Dhouib, A. M. N. Gharbi, and A. M. N. Ben, "Joint optimal production control/preventive maintenance policy for imperfect process manufacturing cell," Int. J. Prod. Econ., vol. 137, no. 1, pp. 126-136, 2012.

[20] M. I. Shahidul and S. T. Syed Shazali, "Dynamics of manufacturing productivity: lesson learnt from labor intensive industries," J. Manuf. Technol. Manag., vol. 22, no. 5, pp. 664-678, 2011.

[21] M. I. Shahidul et al., "Determinants of desalination machinery capacity utilization: evaluate in the aspect of energy, environment and economic sustainability," in Advances in Process Engineering \& Green Energy, 2014.

[22] A. Marucheck and M. McClelland, "Planning Capacity Utilization in an Assemble-toOrder|nEnvironment," Int. J. Oper. Prod. Manag., vol. 12, no. 9, pp. 18-38, 1992.

[23] M. I. Shahidul, H. M. A. Elaswad, and M. D. Lee, "An empirical model to measure engineering management contribution to output growth of machinery manufacturing SMEs," Int. J. Eng. Res. Manag., vol. 3, no. 3, pp. 106-116, 2016.

[24] M. A. Elaswad, M. I. Shahidul, S. T. S. Shazali, and Y. Abdullah, "Evaluate contributions of engineering management to output: a model building approach for manufacturing SMEs," Int. J. Eng. Res. Manag., vol. 2, no. 8, pp. 28-37, 2015.

[25] Y. Qing and D. Izak, "Optimal capacity investment decisions with two-sided fixed-capacity adjustment costs," J. Oper. Res., vol. 55, no. 2, pp. 272-283, 2007.

[26] B. Tamer and O. Ozalp, "Information acquisition for capacity planning via pricing and advance selling: when to stop and act?," J. Oper. Res., vol. 58, no. 51, pp. 328-349, 2010.

[27] M. Mahmood, "Labour productivity and employment in Australian manufacturing SMEs," Int. Entrep. Manag. J., vol. 4, pp. 51-62, 2008.

[28] S. K. Subramaniam, S. H. Husin, and Y. Yusop, "Machine efficiency and man power utilization on production lines," in Proceedings of the 8th WSEAS Int. Conf. on ELECTRONICS, HARDWARE, WIRELESS and OPTICAL COMMUNICATIONS, 2011, pp. 70-75.

[29] H. M. A. Elaswad, M. I. Shahidul, S. T. S. Shazali, and A. Yassin, "Modelling output growth measurement of machinery manufacturing SMEs," Sci. Int., vol. 27, no. 5, pp. 4063-4070, 2015.

[30] R. Clayton, Desalination for Water Supply, Third Edit. Foundation for Water Research, 2015.

[31] G. V. Gude, N. Nirmalakhandan, and S. Deng, "Renewable and sustainable approaches for desalination," Renew. Sustain. Energy Rev., vol. 14, no. 9, pp. 2641-2654, 2010.

[32] A. D. Khawaji, I. K. Kutubkhanah, and J. M. Wie, "Advances in seawater desalination technologies," Desalination, vol. 221, no. 1-3, pp. 47-69, 2008.

[33] J. P. Liyanage, "Operations and Maintenance Performance in Production and Manufacturing Assets: The Sustainability Perspective," J. Manuf. Technol. 
Manag., vol. 18, no. 3, pp. 304-314, 2007.

[34] S. H. Huang et al., "Manufacturing productivity improvement using effectiveness metrics and simulation analysis," Int. J. Prod. Res., vol. 41, no. 3, pp. 513-527, 2003.

[35] S. a. Avlonitis, K. Kouroumbas, and N. Vlachakis, "Energy consumption and membrane replacement cost for seawater RO desalination plants," Desalination, vol. 157, pp. 151-158, 2003.

[36] I. Shahidul, C. H. Ting, M. D. Lee, and S. Begum, "Seawater Desalination for Environment and Economic Sustainability: A Case Study at Sadong Jaya Pilot Plant," Int. J. Eng. Res. Manag., vol. 2, no. 8, pp. 69-74, 2015.

[37] I. Shahidul and S. T. S. Shazali, "Determinants of manufacturing productivity: pilot study on laborintensive industries," Int. J. Product. Perform. Manag., vol. 60, no. 6, pp. 567-582, 2011.

[38] J. G. Wacker, C. L. Yang, and C. Sheu, "Productivity of production labor, non-production labor, and capital: an international study," Int. J. Prod. Econ., vol. 103, no. 2, pp. 863-872, 2006.

[39] N. Ghaffour, T. M. Missimer, and G. L. Amy, "Technical review and evaluation of the economics of water desalination: Current and future challenges for better water supply sustainability," Desalination, vol. 309, no. 2013, pp. 197-207, 2013.

[40] H. Elaswad, S. Islam, S. Tarmizi, A. Yassin, M. D. Lee, and C. H. Ting, "Benchmarking of growth manufacturing SMEs: a review," Sci. Int., vol. 27, no. 3, pp. 2039-2048, 2015.

[41] D. M. Warsinger, J. Swaminathan, E. GuillenBurrieza, H. A. Arafat, and J. H. Lienhard V, "Scaling and fouling in membrane distillation for desalination applications: A review," Desalination, vol. 356, pp. 294-313, 2014.

[42] A. Zhu, P. D. Christofides, and Y. Cohen, "Energy consumption optimization of RO membrane desalination subject to feed salinity fluctuation," IFAC Proc. Vol., vol. 7, no. PART 1, pp. 255-260, 2009.

[43] C. Cabassud and D. Wirth, "Membrane distillation for water desalination: How to chose an appropriate membrane?," Desalination, vol. 157, no. 1-3, pp. $307-$ 314, 2003.

[44] C. W. Cobb and P. H. Douglas, "A Theory of Production," vol. 18, no. 1, pp. 139-165, 1928.

[45] H. Elaswad, S. Islam, S. Tarmizi, A. Yassin, M. D. Lee, and C. H. Ting, "Australian Journal of Basic and Applied Sciences Revealing engineering management contribution ( EMC ) to outputs of manufacturing SMEs : a literature review," Aust. J. Basic Appl. Sci., vol. 8, no. 15, pp. 97-106, 2014.

[46] A. Enshassi, S. Mohamed, P. Mayer, and K. Abed, "Benchmarking masonry labor productivity," Int. J. Product. Perform. Manag., vol. 56, no. 4, pp. 358368, 2007.

[47] A. M. Belay, F. M. Kasie, P. Helo, J. Takala, and D. J. Powell, "Adoption of quality management practices," Benchmarking, vol. 21, no. 1, pp. 77-100, 2014.

[48] M. A. Ismail, A. K. Othman, S. Islam, and H. Zen, "End Suction Centrifugal Pump Operating in Turbine Mode for Microhydro Applications," vol. 2014, 2014.

[49] A. Drak and M. Adato, "Energy recovery consideration in brackish water desalination," Desalination, vol. 339, no. 1, pp. 34-39, 2014.

[50] N. Voutchkov, "Energy use for membrane seawater desalination - current status and trends," Desalination, vol. 431, no. October 2017, pp. 2-14, 2017.

[51] P. S. Goh, W. J. Lau, M. H. D. Othman, and A. F. Ismail, "Membrane fouling in desalination and its mitigation strategies," Desalination, vol. 425, no. August 2017, pp. 130-155, 2018.

[52] M. Wilf and C. Bartels, "Optimization of seawater RO systems design,” Desalination, vol. 173, no. 1, pp. 112, 2005.

[53] S. Atilhan, "A system-integration approach to the optimal design and operation of macroscopic water desalination and supply networks," Texas A\&M University, 2011.

\section{BIOGRAPHIES}

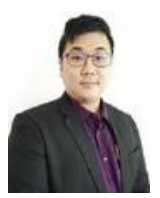

ManDjun Lee obtained his $\mathrm{PhD}$ in Advanced Manufacturing Engineering from University Malaysia Sarawak, Malaysia. His expertise is in the field of operations research, manufacturing operations, modelling on waste reduction, manufacturing productivity and performance, and water treatment. He has published numerous technical papers in the area of water treatment, manufacturing engineering, operations management and operations research.

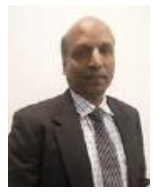

Prahshobh Karunakaranis a registered Professional Engineer (Ir.) in the field of Electrical Engineering. He obtained his PhD. In Manufacturing Engineering (Automation) from the University Malaysia Sarawak, Malaysia. He obtained his BSc and Msc at South Dakota State University, USA. His main interest is in electrical engineering and advanced manufacturing engineering. 


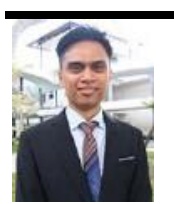

RahmatAidil Djubair, currently a Senior Lecturer and Head of Program for Marketing in University College of Technology Sarawak. He received his bachelor degree both from the University of Malaya and Meio University, Naha City in Okinawa Japan before continuing to pursue his career in banking field at CIMB as a customer service officer taking charge of Japanese and Malaysian customers. 5 years later he pursued his MBA in Korea at Chonnam National University, Gwangju before continue pursuing his career by working in LG as a Product Manager for 5 years in Seoul, Korea. Equipped with language proficiency, he developed and improved his communication and public speaking ability and till now have performed countless of motivation and marketing talks both around the country and international.

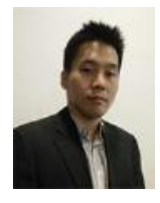

Heng Jong Nguobtained his BEng from Monash University, Melbourne. $\mathrm{He}$ is a registered professional engineer (PE) from the Board of Engineers Malaysia (BEM). He is also a chartered engineer (CPEng) from the Institute of Engineers Australia (IEAUS). His main interest is in the field of manufacturing engineering. 